American Journal of Environmental Sciences 7 (3): 195-199, 2011

ISSN 1553-345X

(C) 2011 Science Publications

\title{
Preservation of the Environment through Sustainable Agriculture Practices: A Case Study on the Attitude of Crop Farmers
}

\author{
Jeffrey Lawrence D’Silva, Bahaman Abu Samah, \\ Hayrol Azril Mohamed Shaffril and Norsida Man \\ Laboratory of Sustainable Development and Agriculture Extension, \\ Institute for Social Science Studies, University Putra Malaysia, \\ Putra Infoport, 43400 Serdang, Selangor Darul Ehsan, Malaysia
}

\begin{abstract}
Problem statement: Undoubtedly agriculture over the years has been a remarkable source of income generator for the rural community to achieve a higher standard of living and to live on par with their urban brethren that are mostly involved in industrialization. The quest for a greater income should, however, not deter farmers from paying attention toward the preservation of the environment in terms of protecting the quality of land, air and water so that our present and future generation will be able to have sufficient resources for their survival. Thus, having a positive attitude toward practicing the elements of sustainable agriculture without doubt will help farmers to emphasize on the need to protect the environment. As such, this study is designed to understand contract farming entrepreneurs' attitude toward the preservation of the environment through sustainable agriculture practices and the issues involved in determining their level of attitude. Approach: The study employed qualitative methodology in the form of a focus group discussion and the data was collected from seven contract farming entrepreneurs in Cameron Highlands, Malaysia. In the data collection process, the researcher played the role as the instrument and an interview guide that was developed prior to it enabled the researcher to achieve the objectives of the study. A couple of voice-recorders assisted in recording the discussion and it was later transformed into verbatim transcripts for data analysis. Results: The outcome of the study showed that in general, crop farmers face an upheaval task in possessing a positive attitude toward practicing sustainable agriculture in spite of having a sound knowledge about it. They perceive that much support is needed from the respective stakeholders that would enable them to embrace sustainable agriculture practices. Conclusion/Recommendations: It is recommended that various stakeholders could play more important roles such as providing trainings to farmers and having a tighter control on prices of crops that will enable farmers to hold a positive attitude on sustainable agriculture practices.
\end{abstract}

Key words: Farming entrepreneurs, group discussion, various stakeholders, agriculture practices, positive attitude, environment through, Development Institute, Organization Authority, collection process, embrace sustainable

\section{INTRODUCTION}

Much has been said on the need for countries globally to focus on agriculture as an important organ in the development process as its contribution is essential in ensuring that the trauma of facing such malaise as scarcity of food and instability in the production of commodities could be hindered. Hence many countries have realized the importance of agriculture and it constitutes a major portion of the annual budget that will ensure more than sufficient commodities are produced so that it could be stocked up to face future calamities such as price instability and poor supply. Malaysia, like many other developing countries, realizes the importance of the agriculture sector (Bahaman et al., 2010) and in the 2011 budget, a total of USD1.6 billion had been allocated solely for agriculture as it believes that agriculture is an important defense to ensure peace and prosperity of its citizens. On top of it, the Malaysian government has also implemented new innovative ways of transforming the agricultural sectors and one of it is the introduction of the contract farming program. In general, the contract farming program involves the various agencies under

Corresponding Author: Jeffrey Lawrence D'Silva, Laboratory of Sustainable Development and Agriculture Extension, Institute for Social Science Studies, University Putra Malaysia, Putra Infoport, 43400 Serdang, Selangor Darul Ehsan, Malaysia 
the Ministry of Agriculture such as the Federal Agricultural Marketing Authority, Agriculture Department, Farmers' Organization Authority, Research and Development Institute and others that will collaborate to help enterprising farmers to enhance production and ensure adequate supply of vegetables and fruits in the market.

As resources are becoming more limited, many countries are feeling the agonizing need to save these resources as they believe that obsessive utilization of resources will bring catastrophe in the future especially in protecting ecosystems. While innovations are being implemented to boost the production of commodities, there exists a great fear that extensive usage of modern technologies in agriculture will lead to many environmental problems and issues and disrupt the long term sustainability of the agronomy systems (Sadati $e t$ al., 2010). In line with this, many environmentalists, ecologists, agricultural professionals, policy makers, farmers and public have voiced out that widespread usage of agriculture technology will lead toward soil degradation, erosion, water pollution, excessive use of chemicals, destruction of natural habitats for wildlife and insects and pests resistance against insecticide and pesticide (Sadati et al., 2010) and thus the need to pay greater attention to sustainable agricultural practices. In general, sustainable agriculture is deemed as an approach whereby production of commodities emphasizes on the need to attain ecological, economic and social sustainability. In line with this, it is believed that the development process with the integration of the dimensions of ecological, economic and social will lead to the attainment of well-managed resources, long term employment and income stability and continuous participation from the farming community in developing land for agriculture purposes. Past literature have cited that accomplishing sustainable agriculture will require paying attention to appropriate usage of fertilizers and pesticides, soil erosion and land degradation and the role extension agents and agriculture agencies play in educating and supporting the farming community (D'Silva et al., 2011).

Despite its' importance, practicing sustainable agriculture is undoubtedly a laborious mission particularly in the minds and hearts of those who grow and harvest crops. Previous studies mentioned on the dimension of attitude as being one of the main stumbling blocks among the entrepreneur farmers (D'Silva et al., 2010a). Based on the existing literature, there are a number of factors that have shown to influence the domain of attitude. One of it is knowledge. According to D'Silva et al. (2010b) knowledge plays an essential role in assisting farmers to embrace sustainable agricultural practices as sound knowledge will help farmers to attain a higher level of competitiveness, enhanced productivity and improvement in the quality of life. Besides that, another important component that might influence the attitude of farmers to accept sustainable agricultural practices is the continuous support it receives from various stakeholders consisting of mainly the policy makers, agriculture agencies and extension officers. The role played by these stakeholders will enable the farmers to garner the much needed support that will assist them in overcoming all the shortcomings they face especially in terms of controlling price instability and the attack of insecticide. On top of it, the dimension of belief too has a great influence on the attitude of farmers to practice sustainable agricultural practices. According to D'Silva et al. (2010a) if farmers believe on the benefits of sustainable agriculture, they will be ready to embrace sustainable agriculture practices and possess a positive attitude towards it.

As being mentioned earlier, the contract farming project is deemed as one of the innovative ways to improve the revenue of farmers besides enhancing the quality of output produced with the implementation of sustainable agriculture practices. In Malaysia through the Ministry of Agriculture and with the aid of various public departments such as the Federal Agricultural Marketing Authority, Agriculture Department, Farmers' Organization Authority, Research and Development Institute has helped to boost the development of contract farming entrepreneurs. Without doubt, the contract farming project is an effective mechanism to eradicate poverty through the adoption of the sustainable agricultural practices and with zealous support from the relevant agricultural agencies it is believed that farmers will be able to become vibrant entrepreneurs in the future. A thorough search of the existing literature showed that not many studies have been conducted to investigate on contract farming entrepreneurs' attitude toward sustainable agricultural practices that will lead them to be attentive toward the preservation of the environment. Hence, this study is designed to determine the attitude of farmers toward sustainable agricultural practices in one of the booming agricultural regions in Malaysia.

\section{MATERIALS AND METHODS}

The methodology used to obtain the data is through a qualitative case study in the form of focus group discussion as this method is deemed suitable to obtain a richer and in-depth insight pertaining to attitude of contract farming entrepreneurs toward the issue of 
Am. J. Environ. Sci., 7 (3): 195-199, 2011

sustainable agricultural practices and preservation of the environment. Cameron Highlands, in Pahang, Malaysia was chosen as the site for the data collection as it is bestowed with a rich rainforest ecosystem and many types of crops are planted here including cabbage, strawberries, tea and so on. A total number of seven experience contract farming entrepreneurs took part voluntarily in the focus group discussion and they are currently diligently working in their respective large farms that produce vegetables for local and international market.

Several guidelines and ethical issues were observed in the process of data collection. Firstly, the role that the researchers played was as the instrument during the data collection process. Then, the researchers had a face-to-face open and transparent discussion with the respondents with the purpose of obtaining meaningful information on the various concerns regarding sustainable agricultural practices. Ultimately, the researchers meticulously analyzed the data that was in the form of transcribed wordings from the respondents in a descriptive manner.

On top of it, before conducting the focus group discussion, a form was distributed to each respondent to elicit information regarding their personel background and basic information. Besides, an interview guide that was formulated prior to the data collection process was used as a guide to achieve the objectives of the study. Furthermore, a couple of voice recorders were also used to assist the researchers to manage the data and to transcribe the data into verbatim transcripts.

\section{RESULTS}

As depicted through the socio-demographic profile of the respondents studied as in Table 1, all the seven contract farming entrepreneurs are males. This indicates that men are willing to take up the challenge of being an entrepreneur and this is in line with many similar scenarios found in developing countries whereby men play the role of a leader and on the other hand women constitute the workforce in enabling production. Besides, there is a fair distribution in terms of race whereby it showed that the Malays and Indians are involved in contract farming. In terms of the age, the mean was identified as 37 years and this shows that farming is indeed gaining popularity among the youth and they do not mind making agriculture as their source of livelihood. The distribution on the level of education showed that a vast majority of them have only secondary education and not up to tertiary level.
Table 1: Socio demographic profile of respondents

\begin{tabular}{|c|c|c|}
\hline Demographic characteristics & Percentage (\%) & Mean \\
\hline \multicolumn{3}{|l|}{ Gender } \\
\hline Male & 100 & \\
\hline Female & 0 & \\
\hline \multicolumn{3}{|l|}{ Race } \\
\hline Malay & 43 & \\
\hline Indian & 57 & \\
\hline Age (years) & & 37 \\
\hline $20-29$ & 29 & \\
\hline $30-39$ & 29 & \\
\hline $40-49$ & 29 & \\
\hline 50 and above & 13 & \\
\hline \multicolumn{3}{|l|}{ Level of education } \\
\hline Second ary & 71 & \\
\hline College & 29 & \\
\hline Monthly income (value in RM) & & 3250 \\
\hline $2000-2999$ & 57 & \\
\hline 3000-3999 & 14 & \\
\hline 4000 and above & 29 & \\
\hline \multicolumn{3}{|l|}{ Farming experience (years) } \\
\hline $1-5$ & 43 & 12 \\
\hline $6-10$ & 14 & \\
\hline 11 and above & 43 & \\
\hline \multicolumn{3}{|l|}{ Number of employed workers } \\
\hline $1-2$ & 29 & 4 \\
\hline $3-4$ & 42 & \\
\hline 5 and above & 29 & \\
\hline
\end{tabular}

Attitude toward sustainable agricultural practices

Hence, there is a need for all concerned parties to encourage more young graduates to partake in farming activities as suggested by Uli et al. (2010). Moreover, Table 1 also showed that farming can be a lucrative career based on the average income of RM3250 gained by the respondents of this study and thus this should be a booster for further involvement of youth in agriculture.

The main objective of this study is to investigate on contract farming entrepreneurs' attitude toward sustainable agriculture practices. Past literature had indicated that knowledge plays an important role in developing favorable attitude toward accepting the fundamentals of sustainable agriculture (Uli et al., 2010). From the discussion with the farmers, it was identified that most of the farmers have a basic knowledge about wise practices of sustainable agriculture. Some of the examples obtained from the informants that described their understanding of sustainable agriculture are as follows:

"If we talk about sustainable agricultural practices, we are talking about how to make use of our land that will bring about good harvest...so when we plant vegetables, we want to plant vegetables for the benefit of the society...meaning we are careful with the usage of pesticide..if we spray today and tomorrow we sell, some of the vegetables might be eaten by our relatives and friends and this might bring health problems to them" (Respondent 1). 
"Less usage of pesticide will not reduce production...I have been planting cabbage since the beginning...I have tried planting other crops but I saw the need to use extensive pesticide...so I focus on cabbage, it is easier, I also practice Integrated Pesticide Management System that assist me in using pesticide adequately" (Respondent 2 ).

In spite of recognizing the importance of sustainable agricultural practices, the respondents still do face many challenges in possessing a favourable attitude toward it. Some of the challenges that they face that hinder them from practicing good sustainable practices are related to price instability, lacking of support from the relevant parties, insufficient monitoring from the relevant agencies pertaining to the usage of pesticide and consumer's inadequate knowledge and awareness toward healthy vegetables.

"Sometimes it is just impossible for us to practice sustainable agriculture. Look at the price of our crops, for example, cabbage that is worth only 40 cents and it is unable even to cover production costs. How are we going to maintain our standard of living? The government has to do something to control the prices of vegetables, monitor the imports of crops and provide us with subsidized pesticides" (Respondent 3 ).

"I have a great desire to minimize the usage of pesticide but sometimes I can't just help it because if I do not use it, my crops will be gone. For instance, my neighbouring farm is involved in the plantation of pudina and the farmer uses pesticide intensively...if I do not use pesticide then my crops will be attacked and I will have to bear big losses" (Respondent 4).

"We are quite surprised that the consumers in our country still emphasize on vegetables that are goodlooking. All the hypermarkets will just ignore any crops that have holes in it...quite clear that they do not mind on the over-usage of pesticides" (Respondent 5).

A good observation from the focus group discussion was the prevalence of the farmers to overdependent on the support from the government. It indicates that to ensure that farmers are able to embrace sustainable agriculture practices, much assistance is needed from the policy makers and government agencies. It seems that the days of putting up signboards that promote farmers to implement good agriculture practices is insufficient. On the other hand, the contract farming entrepreneurs are hoping that more subsidies for planting crops will be given out to them besides conducting more stringent supervision on those who misuse the usage of pesticides so that they will have a favourable attitude to embark on sustainable agriculture practices.

'We actually do not have any doubts regarding sustainable agriculture but the authorities need to support us especially in controlling the prices of our harvest. We do not want to be manipulated by existing middlemen and also hope that the government can provide us with more subsidies" (Respondent 6).

"It is quite ridiculous to see that some of the farmers are able to use over-excessive of pesticides. Surely, the authorities need to do something to overcome this problem. If the government agencies carry out random tests and identify that the level of pesticide usage is high, then the crops should be rejected and the government agencies should not market such crops. And for those who use less pesticide, their crops will be marketed. In this way, we will ensure our market is full of safe crops" (Respondent 7).

\section{DISCUSSION}

The data collected was able to answer the objective of this study that is to determine the attitude of farmers' toward sustainable agriculture that will ensure preservation of the environment. Based on the results, it is clear that the contract farming entrepreneurs in this study have a thorough understanding on the basic concepts of sustainable agriculture. Moreover, they have a strong belief that the future of food production is very much dependent on the continuous practice of sustainable agriculture among the farming community. Hence, this adequate knowledge and belief are positive drivers for crop farmers to attain a positive attitude toward sustainable agricultural practices. However, these contract farming entrepreneurs still need the support from the authorities as they believe that at this stage they are unable to stand on their own feet and this is in line with what had been identified in previous research (D'Silva et al., 2011). The attitude of these farmers will be further boosted if the relevant authorities were able to control the price of crops, prices of inputs for the purpose of production is kept at a low level and tighter control on the usage of pesticides. When these steps are implemented, they believe that they will earn a higher income and will have a peace of mind and a more positive attitude to practice sustainable agriculture.

\section{CONCLUSION}

In general for preservation of the environment and specifically for agriculture sustainability to take place, it is evident that it requires a positive attitude from the farming community. The contract farming entrepreneurs in this study have demonstrated that they are willing to adopt a positive attitude toward sustainable agriculture practices. They exhibit that they also have the fundamental knowledge on what 
sustainable agriculture is all about and they decisively belief on the benefits of practicing sustainable agriculture. Nevertheless, the authorities and agriculture agencies should provide more training to farmers concerning sustainable agricultural practices so that they could further comprehend the essence of sustainable agriculture and thus increase on their level of having a positive attitude toward it. Besides, the authorities could also play a vital role through various mechanisms such as price control, tighter supervision and assisting in reducing the production costs so that farmers can readily have a firm grip on sustainable agricultural practices with an open and peaceful mind. If these suggestions were to be given a serious thought, it is believed that our future generations will not criticize about insufficient resources needed for the process of production of crops.

\section{REFERENCES}

Bahaman, A.S., J.L. D'Silva, H.A.M. Shaffril and U. Jegak, 2010. Acceptance, attitude and knowledge towards agriculture economic activity between rural and urban youth: The case of contract farming. J. Applied Sci., 10: 2310-2315. http://docsdrive.com/pdfs/ansinet/jas/2010/23102315.pdf
D'Silva, J.L., N. Man, H.A.M. Shaffril and B.A. Samah, 2011. Acceptance of sustainability agricultural practices: The case of crop farmers. Am. J. Agric. Biol. Sc., 6: 227-230. DOI: 10.3844/ajabssp.2011.227.230

D'Silva, J.L., H.A.M. Shaffril, J. Uli and B.A. Samah, 2010a. Socio-demography factors that influence youth attitude towards contract farming. Am. J. Applied Sc., 7: 603-608. DOI: 10.3844/ajassp.2010.603.608

D'Silva, J.L., H.A.M. Shaffril, J. Uli and B.A. Samah, 2010b. Acceptance and sustainability of contract farming among youth in Malaysia. Am. J. Agric. Biol. Sc., 5: 350-356. DOI: 10.3844/ajabssp.2010.350.356

Sadati, S.A., H.S. Fami, A. Asadi and S.A. Sadati, 2010. Farmer's attitude on sustainable agriculture and its determinants: A case study in Behbahan Country of Iran, R. J. App. Sc., Eng. Tech., 2: 422427. ISSN: 2040-7467

Uli, J., J.L. D'Silva, H.A.M. Shaffril and A.S. Bahaman, 2010. The attitude, belief, support and knowledge level of the youth and their acceptance towards agriculture contract farming. J. Soc. Sc., 6: 350-355. DOI: $10.3844 /$ jssp.2010.350.355 